Henderson, G. 1978: Development in petroleum exploration offshore West Greenland during 1977. Rapp. Grønlands geol. Unders. 90, 32-36.

Henderson, G., Schiener, E. J., Risum, J. B., Croxton, C. A. \& Andersen, B. B. in press: The West Greenland Basin. Men. Can. Soc. Petrol. Geol. 7.

\title{
Distribution of radioactive mineralisation in central West Greenland
}

\author{
Karsten Secher
}

An airborne radiometric survey 1975-76 (Secher, 1976, 1977) showed several anomalies in the area between Egedesminde and Færingehavn. The follow-up field programme from 1977-79 comprised detailed geological and radiometric mapping, as well as sampling of soil, stream water and stream sediments (Watt, 1977).

Field operations were carried out from the GGU field station at Søndre Strømfjord Airbase, using one helicopter for two to four field parties, each summer. Two GGU cutters were utilised during a part of each season.

There is little previous knowledge of radioactive mineralisation in the area; Bøggild (1953) mentions only a few scattered localities of allanite, and Noe-Nygaard (1958) gives a brief description of allanite-bearing material from the areas east of Sukkertoppen and south of Godthåbsfjord. In the area near Godthåb, allanite has long been known as a rather common accessory in pegmatitic phases of the country rocks (Boucot, 1949). Information in the records of the Geological Museum of Copenhagen mentions monazite showings in the Godthåb and Sukkertoppen districts.

The Phanerozoic carbonatite complex, Qaqarssuk near Sukkertoppen is known to represent an area of locally elevated radioactivity (Secher, 1977), and uraniferous pyrochlore is noted by Gothenborg \& Pedersen (1975). U and Th mineralisations from the Sarfartôq carbonatite complex near Søndre Strømfjord are mentioned in preliminary reports by Secher \& Larsen (in press).

\section{Classification of mineralisation}

Several new observations on radioactive mineralisation were made, and a preliminary classification of them has been made. They can be separated into two main groups: disseminated and vein mineralisation, which can be further divided into subgroups, according to the combination of the characteristic radioactive minerals and the host rock.

Radioactive mineralisations of the disseminated type include: 
(1) Black radioactive mineral (unidentified) in granodioritic gneiss

(2) Monazite in white pegmatite

(3) Allanite in pink pegmatite

(4) Allanite, uraninite and euxenite(?) in white pegmatite

(5) Pyrochlore in sövitic carbonatite

(6) Pyrochlore in rauhaugitic carbonatite

(7) Pyrochlore in beforsitic carbonatite

Radioactive mineralisations of the vein type include:

(1) Pyrochlore in shear zone rocks

(2) Th-minerals (unidentified) in shear zone rocks

(3) Th-minerals (unidentified) in fissure veins

\section{Radioactive mineralisation of disseminated type}

Mineral occurrences in the metamorphic terrain are observed in granodioritic gneiss and pegmatite. U-Th contents in other rock types of the Archaean and the lower Proterozoic Nagssugtoqidian terrain are insignificant. Mineralisation in pegmatite is by far the most abundant, especially in the pegmatite provinces of the Nordre Strømfjord and the Godthåbsfjord districts. Mineralisation in gneiss is found in only a few scattered occurrences.

Disseminated occurrences in igneous rocks occur in the two Phanerozoic carbonatite complexes: Sarfartôq and Qaqarssuk (fig. 19).

(1) Black radioactive mineral (unidentified) in granodioritic gneiss. The mineralisation is found in biotite rich layers within leucocratic gneiss. The mineralised gneiss is located near Nordre Strømfjord and south-east of Holsteinsborg in discrete horizons about $10 \times 200 \mathrm{~m}$. The radioactive mineral resembles altered uraninite in polished sections, with coatings of secondary uraniferous material. Associated minerals are allanite and zircon. The average $U$ content in a mineralised horizon is $20 \mathrm{ppm}$ with a maximum about $380 \mathrm{ppm}$ in small patches. The Th content is $50 \mathrm{ppm}$, and reaches $400 \mathrm{ppm}$ in allanite rich parts.

(2) Monazite in white pegmatite. Monazite is found as $1 / 2$ to $5 \mathrm{~mm}$ orange crystals concentrated in plagioclase-biotite pegmatite and is discordant or concordant with the surrounding biotite gneiss. Associated minerals are garnet, zircon, ilmenite and molybdenite. All occurrences are within granulite facies, clustered in the Nordre Strømfjord region, and also east of Holsteinsborg and in the valley Kûk south-east of Nordre Strømfjord. Several discrete bodies of pegmatite, usually with an area of $5 \times 50 \mathrm{~m}$, contain monazite, and average $c .50$ ppm $U$ and $1000 \mathrm{ppm}$ Th, but reach $250 \mathrm{ppm} \mathrm{U}$ and 1.2 per cent Th in monazite rich lenses.

(3) Allanite in pink pegmatite. Allanite accumulation is found associated with biotite and magnetite in $\mathrm{K}$-feldspar pegmatite. A few examples are known in the Nordre Strømfjord region. The pegmatites are $1-2 \times 50-100 \mathrm{~m}$ in area and are mostly discordant with the surrounding amphibolite facies gneiss. Allanite occurs as euhedral, elongated crystals up to $15 \mathrm{~cm}$ long. Average contents of $U$ and $T h$ in the rock are $3 \mathrm{ppm}$ and $15 \mathrm{ppm}$, respectively. Maximum U value is $75 \mathrm{ppm}$. In allanite-rich parts of the pegmatite Th reaches $100 \mathrm{ppm}$.

(4) Allanite, uraninite and euxenite(?) in white pegmatite. This type of mineralisation occurs in the biotite-rich parts of the pegmatite. The size of single pegmatite bodies varies, and mineralised pegmatites clustered in the Godthåbsfjord region are numerous. The radio- 
Fig. 19. Areas with radioactive mineralisation. Legend: 1 : in gneiss (unidentified $\mathrm{U}$ mineral); 2: in pegmatite (allanite, uraninite, euxenite (?)); 3: in pegmatite (monazite); 4 : in carbonatite complex (pyrochlore); 5 : in shear zones (Th minerals).

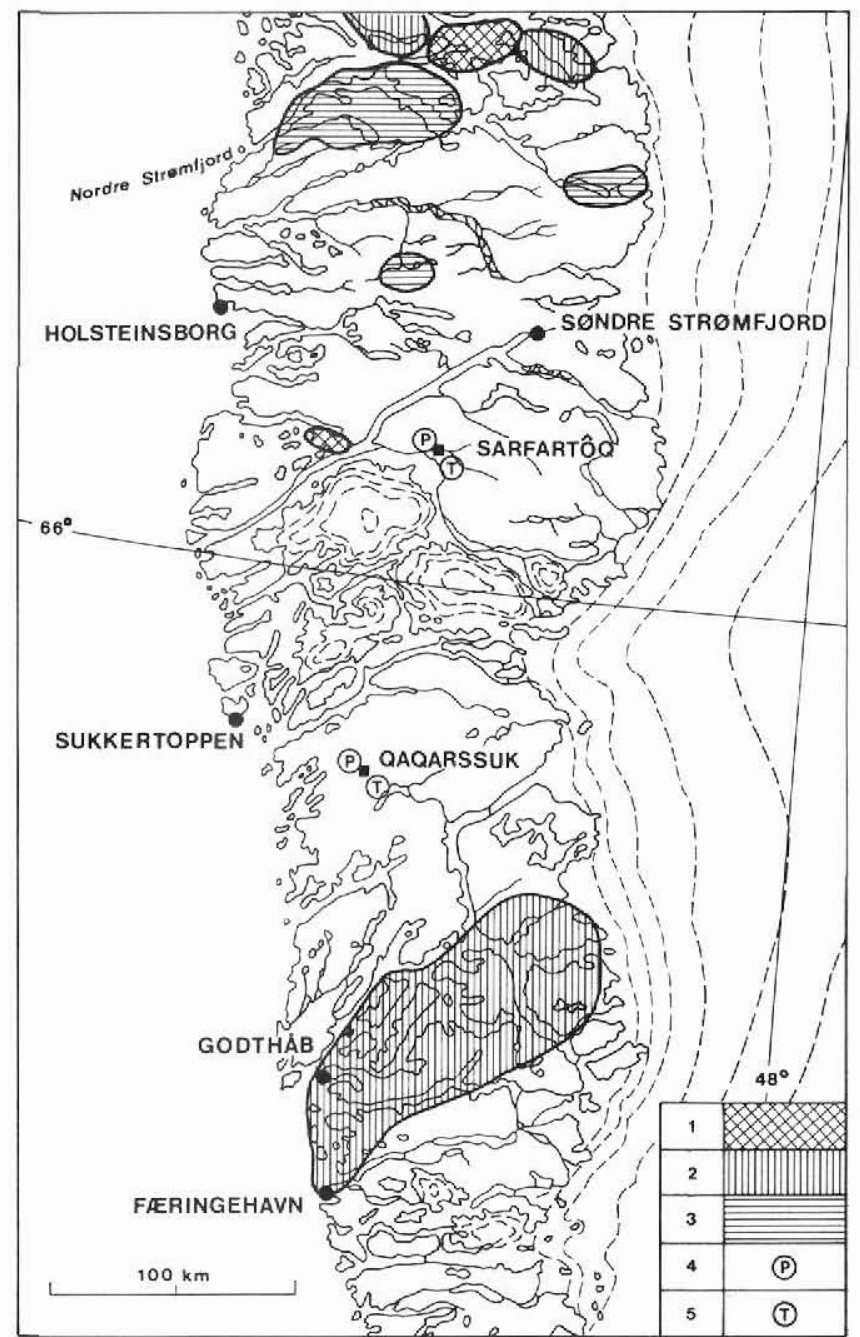

active minerals usually appear as fine-grained material and they do not occur together. Allanite also occurs as coarse crystals up to $5 \mathrm{~cm}$ in length. There are probably at least two generations of allanite, one low and the other high in radioactivity. Uraninite forms fine euhedral crystals, weathering to yellow $\beta$-uranophane. The third radioactive mineral is probably euxenite and it occurs locally as irregular grains. Associated minerals are magnetite, garnet, pyrite and goethite. U content ranges from 10-70 ppm, but uraninite-rich fractions may reach nearly $6000 \mathrm{ppm} \mathrm{U}$. Th content ranges from 30 to $300 \mathrm{ppm}$.

(5) Pyrochlore in sövitic carbonatite. Local concentrations of pyrochlore occur in the major sövitic carbonatite of the Qaqarssuk complex, mainly within certain sheets in its southern and eastern parts. The radioactive mineral occurrences are scattered and usually 
very small. However, several analyses from a $1 / 2 \mathrm{~km}^{2}$ area close to the southern margin of the sövitic core have up to $180 \mathrm{ppm} \mathrm{U}$ and $20 \mathrm{ppm}$ Th. The average values in the sövitic carbonatite are $1 \mathrm{ppm} \mathrm{U}$ and $5 \mathrm{ppm}$ Th.

(6) Pyrochlore in rauhaugitic carbonatite. Pyrochlore mineralisation in the main carbonatite of the Sarfartôq complex is observed occasionally in $1 / 2$ to $1 \mathrm{~m}$ wide rauhaugite sheets of the outer core. Associated minerals are phlogopite, magnetite, apatite and zircon. The narrow rauhaugite sheets average $15 \mathrm{ppm} U$ and $5 \mathrm{ppm} T \mathrm{Th}$, with local maximums of 400 ppm U and 20 ppm Th.

(7) Pyrochlore in beforsitic carbonatite. Pyrochlore enrichment is observed in beforsite carbonatite dykes of the Sarfartôq complex. The dykes are considered to be a younger stage of the carbonatite activity, and thus represent a second phase of pyrochlore accumulation within the magmatic evolution of the complex. The pyrochlore is very fine grained, and is associated with aptite in the beforsite dykes, $20-40 \mathrm{~cm}$ wide, traceable for not more than $30 \mathrm{~m}$. Average values are $10 \mathrm{ppm} \mathrm{U}$ and $75 \mathrm{ppm}$ Th, reaching $140 \mathrm{ppm} \mathrm{U}$ and $200 \mathrm{ppm}$ Th.

\section{Radioactive mineralisation of vein type}

Radioactive mineralisation in veins is related only to the Phanerozoic carbonatite complexes. The origin of the mineralisation is hydrogenic; either hydrothermal or caused by remobilisation, characteristically in shear and fracture zones.

(1) Pyrochlore in shear zone rocks. Pyrochlore mineralisation occurs in the Sarfartôq complex, near the margin of the fenite area, in zones oriented tangentially to the complex. They represent a third generation of uraniferous pyrochlore related to carbonatite. The pyrochlore is associated with aegirine and hematite on fractures in highly cataclastic rocks. This intense phase of mineralisation formed nearly massive, mostly small, pyrochlore concentrations, but one $10 \times 100 \mathrm{~m}$ zone containing 5000-10 $000 \mathrm{ppm} \mathrm{U}$ and 700-1000 ppm Th was found.

(2) Th-minerals (unidentified) in shear zone rocks. Narrow Th-mineralised zones with intense shearing and carbonatite veining are frequently found in the marginal parts of the Sarfartôq complex. This mineralisation is shown to have formed during a hydrogenic stage of the carbonatite activity by the associated chlorite, hematite, REE-carbonate, barite, galena, sphalerite and goethite. These zones are seldom larger than $1 \times 50 \mathrm{~m}$, and average 3000 ppm Th, reaching up to 1.2 per cent, and 5-10 ppm U.

(3) Th-minerals (unidentified) in fissure veins. Th-enrichments are detected in a concentric zone with frequent fissures and slickensides along the periphery of the Qaqarssuk complex. Associated minerals are fibrous amphibole and goethite. Data on the $U$ and Th contents are not available.

\section{Concluding remarks}

Radioactive mineral occurrences in central West Greenland are classified into two major groups: disseminated and vein types. They have been further divided, on the bases of their mineralogy and host rocks, into ten subgroups.

The monazite-bearing pegmatites in the Nordre Strømfjord area are classified as a disse- 
minated type of mineralisation and contain a rather high percentage of radioelements. Enrichments of allanite are most frequent in amphibolite facies environments, with low $\mathrm{Th}$. Uraninite mineralised rocks locally have a very high $U$ content, but they occur only in small isolated spots. Comparison between the radioactive mineral occurrences of the Nordre Strømfjord area shows a positive correlation between increasing metamorphic grade, thorium and the occurrence of monazite.

Vein type mineralisation is represented by uraniferous pyrochlore and Th-mineral enrichments in shear zones within the carbonatite complexes. By far the most interesting mineral occurrence is the vein type pyrochlore mineralisation in the Sarfartôq complex. This represents one of three pyrochlore phases related to the carbonatite activity, where $U$ and also $\mathrm{Nb}$ and REE are exceptionally concentrated due to very favourable depositional controls.

\section{References}

Boucot, A. J. 1949: Allanite from Godhaab, South Greenland. Rocks and Minerals 24, 35 and 61. Bøggild, O. B. 1953: The mineralogy of Greenland. Meddr Grønland 149(3), 1-442.

Gothenborg, J. \& Pedersen, J. L. 1975: Exploration of the Qaqarssuk carbonatite complex 1975, part II. Kryolitselskabet Øresund A/S, Unpublished company report.

Noe-Nygaard, A. 1958: En undersøgelse af prøver af allanit fra Grønland. Unpublished GGU report, $14 \mathrm{pp}$.

Secher, K. 1976: Airborne radiometric survey between $66^{\circ}$ and $69^{\circ} \mathrm{N}$, southern and central West Greenland. Rapp. Grønlands geol. Unders. 80, 65-67.

Secher, K. 1977: Airborne radiometric survey between $63^{\circ}$ and $66^{\circ} \mathrm{N}$, southern West Greenland. Rapp. Grønlands geol. Unders. 85, 49-50.

Secher, K. \& Larsen, L. M. (in press): Geology and mineralogy of the Sarfartôq carbonatite complex, southern West Greenland. Lithos.

Watt, M. 1977: Geokemisk prøveindsamling i Nordre Strømfjord og Sarfartôq, centrale Vestgrønland. Unpublished GGU report, 12 pp.

\section{Lamprophyric and kimberlitic dykes associated with the Sarfartôq carbonatite complex, southern West Greenland}

\section{Lotte Melchior Larsen}

Lamprophyric and kimberlitic dykes are known to be widely distributed in the Holsteinsborg - Søndre Strømfjord area. Escher \& Watterson (1973) published a map showing dyke concentrations in two areas, the coastal region between Holsteinsborg and Itivdleq, and an inland area between Søndre Strømfjord and Sukkertoppen Iskappe. In the latter area the 90 $\mathrm{km}^{2}$ Sarfartôq carbonatite complex was discovered in 1975 (Secher \& Larsen, 1978, and in press). During the 1979 field season in this area, numerous lamprophyric and kimberlitic 